\title{
Nothing is new, but everything has changed: A viewpoint on the future school
}

\author{
António Nóvoa ${ }^{1}$ Yara Alvim²
}

\begin{abstract}
This Viewpoint argues that the debates about the future of education and the need to rethink the school model started long before the pandemic crisis. But the situation we are experiencing has accelerated this need and showed that changes are possible. Consumerist trends in education have been accentuated, now with the massive use of digital tools. These trends, which, since the beginning of the twenty-first century, have supported "personalization of learning", can lead to the disintegration of the school. But dynamics of transformation and metamorphosis of the school have also emerged, reinforcing education as a public and common good. The authors seek to enunciate these dynamics that redefine three bases of the school model: the social contract around education, the organizational structure of the school, and the pedagogy of the lesson.
\end{abstract}

Keywords Future of education - Pandemic $\cdot$ Education change $\cdot$ Metamorphosis of the school

All the 20th century futurologies that predicted the future by carrying currents through the present into the future have collapsed. Yet we continue to predict 2025 and 2050 while we are unable to understand 2020. The experience of the eruption of the unexpected in history has barely penetrated consciousness. The

António Nóvoa

novoa@reitoria.ul.pt

Yara Alvim

yara.alvim@uff.edu.br

1 Institute of Education, University of Lisbon, Alameda da Universidade, 1649-013 Lisbon, Portugal

2 Faculty of Education, Federal University of Juiz de Fora, Rua José Lourenço Kelmer, Juiz de Fora, MG 36036-900, Brazil 
arrival of the unpredictable was foreseeable, but not its nature. Hence my permanent maxim: "Expect the unexpected".

Morin 2020, p.3.

\section{Rethinking the school model}

A point of view is a view from a point, from a given position. Our point of view is the long felt need to transform a school model that, having been built in the nineteenth century, spanned the twentieth century and arrived, showing signs of fragility, in the twenty-first century. The pandemic just made inevitable what was already needed.

Many of us have written, in recent years, about the end of the school model (Nóvoa 2006) and the need to rethink the institutional bases of the school. See, on this matter, The One Best System (1974) by David Tyack, and his Tinkering toward Utopia (1995), in collaboration with Larry Cuban. The reinforcement of education as a public and common good is the beacon that guides the transformations we support.

Let us point out, in rough lines, three dimensions of the school model that need to be rethought today:

First: The acceptance of a social contract that assigns the primary responsibility for the education of children to specialized education systems.

Second: The consolidation of an organizational structure, built around a delimited school space whose central reference is the classroom, in which activities are developed with precise schedules.

Third: The consecration of the lesson as the basis of a pedagogy that can be explained through the "blackboard metaphor", in which a teacher lectures a relatively homogeneous class of students.

Although simplistic, almost to the point of caricature, this description allows us to mark three essential aspects of the process of change or metamorphosis of the school (Nóvoa 2019). It is true that the twentieth century was fertile for debates and pedagogical innovations, but the school model has hardly changed. At least, until the pandemic crisis.

In early 2020, the world was surprised by COVID-19. Suddenly, in a few days, what was considered impossible became possible: the untouched space of the classroom gave rise to a diversity of learning spaces, especially at home; school hours, which could not be changed due to the organization of family life and work, became volatile; teaching methods centred on the classroom disappeared and a diversification of approaches, mainly through remote learning, took place, and so on. Need prevailed over inertia, albeit with fragile and precarious solutions.

\section{The "death of the school"}

Various groups and authors have been announcing, at least since the beginning of the twenty-first century, the "death of the school". It is not easy to outline a synthesis of these trends, which have different origins and perspectives. Perhaps their common denominator is the definition of education as a "private good", placing the focus not so much on education as on learning (and this language change is not innocent), and assuming that the most important thing is to respond to the individual needs of each student. 
In one way or another, these trends emphasize a consumerist approach to education. Their arguments are based on the mobilization of the usual concepts-choice, competition, accountability, efficiency ... - redefining the student as a consumer. In this way, education is called into question as a public and common good.

Two of these trends, perhaps the most influential, will be highlighted shortly. On one hand, there is a disparate set of authors who elaborate on the digital transition, artificial intelligence, and machine learning, calling for new forms of learning that are increasingly "personalized" through a systematic use of technologies. Alexandre (2019), for example, believes that the future will bring an increased "individualization of teaching thanks to a growing use of digital technologies boosted with AI", even stating that "school will become transhumanist and will find it normal to modify the brains of the students using all the panoply of NBIC technologies" (p. 203).

These authors were prepared to respond to the emergency situation created by the pandemic, through the mobilization of online platforms and teaching materials. In a sense, it was the opportunity they had been waiting for. However, it would be tragic - for the public dimension of education, for the autonomy of schools, and for teachers' professionalism-if the answers to the urgency of the crisis served as the pretext for establishing a new educational norm based on these proposals.

On the other hand, we find many scholars who, in the last decades, gathered around the so-called "learning sciences". Brain studies and learning are a powerful symbolic universe, reinforcing the idea that it is possible to find personalized responses for each child and that these responses can be given in a domestic setting. The basic idea is to build an evidencebased education along the same lines as evidence-based medicine. Educational neuroscience seeks to calculate the educational and pedagogical universe by explaining learning through scientific research of the brain.

These scholars were also prepared to respond to the pandemic crisis, with many families retiring to protected and confined spaces and looking for individualized answers for their children. Most of the digital materials made available during the pandemic followed this matrix. However, it would be tragic for educators to perpetuate these practices over time, as education requires human relationships and interaction and cannot be fully accomplished in isolation and with "social distancing".

The call for a "personalization" of learning in "domestic" spaces, through the use of a panoply of digital means leads to the disintegration of the school. Obviously, we are not denying the importance of digital tools and learning sciences, which are central to rethink education. But we must subordinate these approaches to a transformation of the school model that does not diminish but, rather, reinforces education as a public and common good.

\section{Lessons learned in responding to the pandemic}

Let us return to the three dimensions of the school model mentioned at the beginning of this article, in order to assess, briefly, the educational responses given during the pandemic.

First: In general, the response of national education systems was fragile and inconsistent. Ministers and public authorities were dependent on platforms and content made available by private companies and were not even able to ensure digital access for all students.

Second: The response at the school level was, in many cases, much better. Many schools were able to deploy more adequate solutions, especially when there was a good connection 
with families and the support of local authorities. The importance of the bonds of trust between schools, families, students, and local communities became evident.

Third: However, the best answers came from the teachers themselves, who, through their professional autonomy and collaboration dynamics, offered robust proposals that made pedagogical sense and addressed concerns about inclusion. More than ever, it has become clear that teachers are essential to the present and future of education.

In recent weeks, numerous publications describing the responses of different countries to the pandemic confirm this assessment (Reimers and Schleicher 2020; UNESCO 2020). In terms of education, the most relevant lessons from this pandemic highlight the importance of teachers and the construction of new educational environments. This health crisis has made it clear that the potential for response lies more with teachers than with policies or institutions.

Well-prepared teachers, with autonomy, working together inside and outside the school space, in connection with families are always the best guarantee of timely and appropriate solutions. The reinforcement of teachers' professionalism is fundamental. We must invest in teacher education and curriculum policies that ensure and acknowledge teaching autonomy. We need to strengthen teachers' capacity for action and professional collaboration.

Further, teachers and schools must have the capacity for initiative, adaptation, and change. Uniform and rigid structures have no future. Openness is needed to define different solutions, different educational, school, and pedagogical projects. Most important is the construction of coherent educational environments that allow what we have long argued for: involvement and participation of students; valuing of knowledge, study, and research; cooperative learning; integrated and multi-thematic curricula; pedagogical differentiation; etc.

Ten years ago, in a remarkable article published in Le Monde, the French philosopher Morin (2010) wrote that when a system is unable to solve its vital problems either it degrades, or it is capable of a gesture of metamorphosis. And, he added, referring to the Earth system: "Disintegration is probable. Metamorphosis is improbable, but possible" (Morin 2010).

What is true for the Earth's natural system is also true for the education system. Metamorphosis is the renewal, not the "death" of school. As one possibility, we can move toward disintegration and increasing consumerism in education. Most of the responses to the COVID-19 crisis reinforce this trend. But metamorphosis is also still possible, as can be seen in many initiatives taken by teachers and schools, which were able to reinvent pedagogy and learning environments, to increase the porosity of educational life in its connection with public spaces—with the polis, the city.

\section{The post-pandemic school, after the school model}

It is difficult to write the history of the future, but necessary. We do not want the disintegration of the school but, rather, its profound transformation in the context of new relations with society and knowledge, always valuing teachers and a humanist vision of education. Like Greene (1982), we cannot imagine a coherent sense of purpose in education if something common does not arise in a public space.

Thus, summarizing the three dimensions of the school model presented at the beginning of this viewpoint - the social contract celebrated in the nineteenth century, the spatial-temporal structure of the school, and the pedagogy of the lesson-we would like the 
transformation of the school to be inspired by countless initiatives and experiences that already exist throughout the world. We will take the risk of sketching out some scenarios, not to embark on a futuristic exercise but rather to try to take some steps toward the metamorphosis of the school.

First: The idea of a social contract that assigns almost complete responsibility for education to the school no longer makes sense. We need to build a public space for education that is broader than the school space, stricto sensu. What does this mean? We must recognize the importance of educational capillarity; that is, of educational processes that take place inside and outside the school, through formal and informal means. Fifty years ago, the Permanent Education movement already had this idea in mind when it enshrined the principle that people learn in various places and in various ways, supporting the need for the recognition of prior learning achieved through life, experience, and work. The metaphor of the Educating Cities also illustrates this intention. Many responses to the pandemic, all over the world, revealed the importance of this capillarity in connection with families, but also in understanding that education goes far beyond the reality of school. The construction of this new social contract centred around education, which implies the existence of participation and democratic deliberation, is essential to rethink the school model.

Second: It is necessary to transform the organizational structure of the school. We all know of the nineteenth-century great historical project for the normalization of the school: spaces, times, curricula, assessment of learning, role of teachers, grouping of students... Everything was subjected to a logic of normalization, well-illustrated by the name given to teacher-training institutions: normal schools. Today, the opposite movement is required: diversification of spaces and times, curricula and forms of assessment, the work of teachers and students... What does this mean? The creation of new educational environments, very different from the traditional classroom space, which allow individual study and group work, monitoring by teachers, and research projects, face-to-face, and digital work. Metaphorically, we can imagine these new environments as a large library: some students study alone, connected to the internet or not; others work in groups; others discuss with one or more teachers; others develop a research project; others present their work; others are in contact with people outside, perhaps even abroad...

Third: The idea of a standard pedagogy around the lesson has to give way to pedagogies that value a diversity of methods and modalities of study and work. The lesson has an important function, as a space for synthesis, but can never be the exclusive, or even the main, activity. Pedagogy cannot revolve around "lesson" but, rather, "study". What does this mean? A profound change in the day-to-day school life of students and teachers. On one hand, removing students from the "school desk" and putting them on an active search for knowledge. On the other hand, emphasizing the responsibility of teachers in relation to the overall educational work (organizing contents and research, monitoring, tutoring, support, etc., and not just "lessons"), reinforcing their collaborative action and their autonomy in the production of pedagogical and curricular knowledge. The best responses to the pandemic were the result of collaboration between groups of teachers, from the same school and from different schools, who were able to present innovative ideas and projects, maintaining links with students and managing to keep them mobilized from the point of view of knowledge, learning, and education. 


\section{Conclusions}

None of this is new. The school model has long found it difficult to meet the needs of students in our century. Many educators and families were already aware of the need to change the school model, but the pandemic revealed the urgency and the possibility of this transformation. In just a few days it was possible to change what many considered impossible to change. Of course, all of this was "made possible" by the need to preserve public health and respond to a crisis of global proportions. But it showed that change is realizable. For many, this change is mainly digital or technological, as if everything could now be done virtually and remotely. That would be a highly undesirable transformation. Central dimensions of education would be lost-human interaction, conviviality, learning to live in common. Consumerist tendencies would be accentuated and public aspects would be lost.

We can risk a prediction. Contrary to what is heard every day, neither a new world nor a new school will arise as a result of the pandemic. Sooner rather than later, schools will return to their traditional routines. But the pandemic revealed that, in addition to being necessary, change is urgent and possible. It is this awareness that invites us, today, to take steps, even modest ones, toward a future school. After the pandemic, perhaps the most likely outcome is an acceleration of the disintegration of the school. But metamorphosis is still possible.

Education is always defined over a very long time, never a short one. But at certain moments, as the one we live in, the choices we have before us are absolutely decisive. There are no inevitabilities, nor are histories already decided. Every day, we define a little, or a lot, of the history of the future.

\section{References}

Alexandre, L. (2019). La guerre des intelligences: Comment l'intelligence artificielle va révolutionner l'éducation. Paris: Le livre de poche.

Greene, M. (1982). Public education and the public space. Educational Researcher, 11(6), 4-9.

Morin, E. (2010). Éloge de la métamorphose. Le Monde. https://www.lemonde.fr/idees/article/2010/01/09/ eloge-de-la-metamorphose-par-edgar-morin_1289625_3232.html.

Morin, E. (2020). Un festival d'incertitudes. Tracts de crise: Un virus et des hommes (pp. 404-419). Paris: Gallimard.

Nóvoa, A. (2006). La construction du modèle scolaire dans l'Europe du Sud-Ouest. Paris: Université de Paris IV-Sorbonne.

Nóvoa, A. (2019). Teachers and their education at a time of school metamorphosis. Educação \& Realidade, 44(3), 1-14.

Reimers, F. \& Schleicher, A. (2020). Schooling disrupted, schooling rethought: How the Covid-19 pandemic is changing education. Paris: OECD.

Tyack, D. (1974). The one best system. Cambridge, MA: Harvard University Press.

Tyack, D. \& Cuban, L. (1995). Tinkering toward Utopia. Cambridge, MA: Harvard University Press.

UNESCO (2020). UNESCO's support: Educational response to COVID-19. https://en.unesco.org/covid19/ educationresponse/support.

Publisher's Note Springer Nature remains neutral with regard to jurisdictional claims in published maps and institutional affiliations.

António Nóvoa is Full Professor at the Institute of Education, University of Lisbon. Currently, he serves as the Ambassador of Portugal to UNESCO. Between 2006 and 2013, he was President of the University of Lisbon. He earned a PhD in history, from Sorbonne University, and a PhD in Educational Sciences, from University of Geneva. Several Brazilian and Portuguese universities have awarded him the title of Doctor Honoris Causa. Throughout his academic career, Dr. Nóvoa has been Professor at several international universities (Geneva, Wisconsin-Madison, Oxford, and Columbia-New York), and Visiting Professor for 
short periods in 20 universities around the world. Between 2000 and 2003, he served as President of ISCHE [International Standing Conference for the History of Education]. He published more than 200 texts (books and articles), in the areas of history of education, comparative education, and teacher education.

Yara Alvim is Professor at the Faculty of Education of the Federal University of Juiz de Fora (MG-Brazil), working in the initial and continuing education of teachers in the areas of history and pedagogy. She received her $\mathrm{PhD}$ in education from the Federal University of Rio de Janeiro. Dr. Alvim has experience in initial and continuing education, through the PIBID [Institutional Grant Program for Initial Teacher Education] and the Teaching Residency Program (UFJF). She coordinates the Research Group in History Teaching $(\mathrm{CNPq})$, from which she has developed her actions of university extension and research in History Teaching. 